\title{
Complicações Respiratórias em Pacientes com Paralisia Cerebral Submetidos à Anestesia Geral*
}

\section{Respiratory Complications in Patients with Cerebral Palsy Undergoing General Anesthesia}

\author{
Sérgio Silva de Mello, TSA ${ }^{1}$, Ronaldo Soares Marques, $T S A^{1}$, Renato Ângelo Saraiva, TSA
}

\section{RESUMO}

Mello SS, Marques RS, Saraiva RA - Complicações Respiratórias em Pacientes com Paralisia Cerebral Submetidos à Anestesia Geral.

JUSTIFICATIVA E OBJETIVOS: Anestesia em pacientes com paralisia cerebral $(P C)$ pode representar um desafio para o anestesiologista. Este estudo prospectivo teve como objetivo determinar a prevalência e o risco de complicações respiratórias em crianças com PC submetidas à anestesia geral inalatória (AGI) para tomografia computadorizada (TC).

MÉTODO: Participaram do estudo pacientes com idades entre 1 e 17 anos, estado físico ASA I a III, submetidos a AGI com sevoflurano e máscara laríngea para TC no período de junho/2002 a junho/2003, divididos em três grupos: $P C$ tetraplégicos (PCT), outros tipos de $P C$ ( $P C O$ ) e paciente sem $P C$ (NPC). Os pais ou responsáveis responderam a um questionário com perguntas sobre $O$ histórico médico dos pacientes, infecção de vias aéreas superiores (IVAS), asma, convulsão, incoordenação orofaríngea, refluxo gastroesofágico, etc. Dados sobre incidência e gravidade das complicações respiratórias foram coletados prospectivamente (tosse, broncoespasmo, laringoespasmo, hipoxemia, aspiração). A amostra foi calculada para uma incidência esperada de $5 \%$ no grupo NPC, com uma diferença de $15 \%$ entre os grupos $(\alpha=0,05$ e $\beta=0,1)$, utilizando-se os testes do Qui-quadrado, exato de Fisher e $t$ de Student.

RESULTADOS: Compuseram a amostra 290 pacientes divididos nos grupos da seguinte forma: PCT - 100, PCO - 79 e NPC - 111. Não houve diferença na prevalência de complicações respiratórias entre os grupos PCT (4\%), PCO (8,9\%) e NPC (7,3\%). Houve associação entre a presença de IVAS e a ocorrência de complicações (risco relativo, 10,71).

\footnotetext{
${ }^{*}$ Recebido da (Received from) Rede Sarah de Hospitais do Aparelho Locomotor, Unidade Belo Horizonte, MG

1. Anestesiologista da Rede Sarah de Hospitais do Aparelho Locomotor 2. Coordenador de Anestesiologia da Rede Sarah de Hospitais do Aparelho Locomotor

Apresentado (Submitted) em 27 de outubro de 2006

Aceito (Accepted) para publicação em 26 de junho de 2007

Endereço para Correspondência (Correspondence to)

Dr. Sérgio Silva de Mello

Hospital Sarah Belo Horizonte - Área de Anestesiologia

Av. Amazonas, 5.953 - Gameleira

30510-000 Belo Horizonte, MG

E-mail: sergiomello@sarah.br

(C) Sociedade Brasileira de Anestesiologia, 2007
}

CONCLUSÕES: Crianças com paralisia cerebral tipo tetraplegia espástica não parecem ter um risco aumentado de complicações respiratórias durante anestesia geral inalatória com sevoflurano e máscara laríngea. O estudo confirma IVAS como fator de risco para a ocorrência dessas complicações.

Unitermos: ANESTESIA, Geral: inalatória; DOENÇAS, neurológica: paralisia cerebral; COMPLICAÇÕES: respiratórias

\section{SUMMARY}

Mello SS, Marques RS, Saraiva RA - Respiratory Complications in Patients with Cerebral Palsy Undergoing General Anesthesia.

BACKGROUND AND OBJETIVES: Anesthesia in patients with cerebral palsy $(C P)$ poses a challenge for the anesthesiologist. The objective of this prospective study was to determine the prevalence and risk of respiratory complications in children with CP undergoing general inhalational anesthesia for computed tomography.

METHODS: Patients with ages ranging from 1 to 17 years, physical status ASA I to III, undergoing general inhalational anesthesia with sevoflurane and laryngeal mask for a CT scan from June 2002 to June 2003, participated in this study. Patients were divided in 3 groups: quadriplegic $C P(C P Q)$, other types of $C P(C P O)$, and patients without CP (NCP). Parents or guardians answered a questionnaire that assessed the past medical history of the patient, upper respiratory infections (URI), asthma, seizures, oropharyngeal dysfunction, gastroesophageal reflux, etc. Data on the incidence and severity of respiratory complications were gathered prospectively (cough, bronchospasm, laryngeal spasm, hypoxemia, aspiration, etc). The size of the study group was calculated for an expected $5 \%$ incidence in the NCP group, with a 15\% difference among groups ( $\alpha=0.05$ and $\beta=0.1$ ), using the Chi-square test, Fisher exact test, and test $t$ Student.

RESULTS: Two hundred and ninety patients, divided in three groups, participated in this study. Groups were composed of: CPQ $=100$ patients, $C P O=79$ patients, and NCP $=111$ patients. There were no differences on the prevalence of respiratory infections among the CPQ (4\%), CPO (8.9\%), and NCP (7.3\%) groups. There was a correlation between the presence of URI and the development of complications (relative risk of 10.71).

CONCLUSIONS: Children with cerebral palsy with spastic quadriplegia do not seem to have an increased risk of respiratory complications during general inhalational anesthesia with sevoflurane and laryngeal mask. This study confirms URI as a risk factor for the development of those complications.

Key Words: ANESTHESIA, General: inhalation; COMPLICATION: respiratory; DISEASES, Neurologic: cerebral palsy. 


\section{INTRODUÇÃO}

Paralisia cerebral (PC) compreende um grupo de desordens no desenvolvimento do movimento e postura causando limitação da atividade, que são atribuídos a distúrbios não-progressivos que ocorrem no encéfalo fetal e infantil em desenvolvimento. Essa desordem motora é em muitos casos acompanhada de distúrbios da sensação, cognição, comunicação, percepção, comportamento e convulsões ${ }^{1}$. A incidência de crianças que sobrevivem a agressões orgânicas sofridas no período pré-, peri- ou pós-natal vem se mantendo constante nas últimas décadas nos países desenvolvidos ${ }^{2}$. Uma parcela significativa desses pacientes submete-se, em algum momento de suas vidas, a um procedimento anestésico para fins propedêuticos ou terapêuticos. A presença de doenças associadas à lesão cerebral, como refluxo gastroesofágico (RGE), incoordenação orofaríngea (IOF) e acúmulo de secreção, além de convulsões e a incoordenação motora, podem contribuir para o aumento da ocorrência de complicações respiratórias durante anestesia geral nesses pacientes ${ }^{3,4}$.

Este estudo foi idealizado com o intuito de verificar a prevalência de complicações respiratórias em crianças com PC submetidas à anestesia geral inalatória (AGI) para realização de tomografia computadorizada (TC), comparada com a de crianças sem essa doença. Além disso, outros fatores de risco relacionados ao aparecimento dessas complicações também foram investigados.

\section{MÉTODO}

O estudo foi aprovado pelo Comitê de Ética da instituição e consentimento pós-informado foi obtido dos pais ou responsáveis legais dos pacientes. A amostra foi constituída de 290 pacientes de 1 a 17 anos, com TC de encéfalo programada sob anestesia geral no período de $1^{\circ}$ junho de 2001 a $1^{\circ}$ de junho de 2002, divididos em três grupos: pacientes com PC tipo tetraplegia espástica (PCT); pacientes com outras classificações de PC, quais sejam, diplegia espástica, hemiplegia espástica e coreoatetose (PCO); e crianças sem PC (NPC). Foram excluídos pacientes com síndromes genéticas, outras doenças diagnosticadas do sistema nervoso central (SNC), sinais de infecção de vias aéreas superiores (IVAS) com acometimento sistêmico ou infecção bacteriana de vias aéreas inferiores.

Antes do procedimento os responsáveis pelos pacientes foram convidados a preencher um formulário de adesão ao estudo com informações demográficas da família, história de IVAS atual ou recente (< três semanas), asma, prematuridade (< 37 semanas), tabagismo dos pais. Além disso, pesquisou-se a presença associada de asma, IOF diagnosticada por videofluoroscopia, RGE grave diagnosticado por endoscopia, uso de medicação anti-refluxo, convulsões e uso de anticonvulsivantes, história de pneumonias de re- petição e alergias. A classificação do tipo de PC era feita a partir dos dados contidos no prontuário eletrônico e confirmado com o profissional responsável pelo paciente.

Anestesia - Todos os pacientes foram submetidos a anestesia geral inalatória com sevoflurano associado a $\mathrm{N}_{2} \mathrm{O}$, em circuito sem válvula, sem absorvedor de $\mathrm{CO}_{2} \mathrm{e}$ com a monitoração das variáveis fisiológicas cardiovasculares e respiratórias, sendo a fração expirada final (alveolar) do anestésico mantida a 0,5 CAM durante todo o procedimento. A manutenção das vias aéreas foi feita com máscara laríngea e os pacientes permaneceram em ventilação espontânea durante todo o exame, com níveis de $\mathrm{P}_{\mathrm{ET}} \mathrm{CO}_{2}$ e $\mathrm{SpO}_{2}$ dentro dos limites da normalidade. As eventuais dificuldades na introdução e adaptação da máscara laríngea foram registradas, bem como a duração da anestesia.

Caracterização dos eventos respiratórios - Foram considerados como eventos respiratórios os seguintes sinais e sintomas devidamente registrados na ficha de anestesia e na ficha apropriada: hipoxemia considerada como $\mathrm{SpO}_{2}<90 \%$ mantida por mais de 20 segundos, laringoespasmo, broncoespasmo, tosse intensa por mais de 15 segundos, aspiração pulmonar clinicamente detectável de conteúdo gástrico. O momento e a intensidade da intercorrência também foram registrados: indução, manutenção, despertar e pós-anestésico (1-4); sem complicações, grau leve, moderado ou intenso $(1-4)$.

Foi também registrada a magnitude da intervenção realizada: 1. Simples: oxigênio $\left(\mathrm{O}_{2}\right)$ sob máscara; 2 . Moderada: $\mathrm{O}_{2}$ sob máscara + succinilcolina ou atropina; 3 . Complexa: $\mathrm{O}_{2}+$ fármacos + intubação traqueal; e 4. Reanimação cardiopulmonar (RCP).

O sucesso das medidas foi avaliado pela evolução: 1. Favorável; 2. Desfavorável - seqüela ou óbito. Foram comparados: freqüência das complicações, momento ocorrido, tipo de intervenção necessária e evolução do quadro.

A análise estatística foi realizada utilizando o software SPSS ${ }^{\oplus}$ versão 10.0.1. Assumindo que o risco de complicações respiratórias em crianças sem PC seria em torno de $5 \%$ e que crianças com formas menos graves de PC teriam prevalência semelhante, esperava-se empiricamente prevalência quatro vezes maior em crianças com PC na sua forma mais grave (tetraplegia espástica). Considerando o poder de 0,8 (1- $\beta$ ) e $\alpha=0,05$, o tamanho sugerido da amostra seria de 227 crianças (76 por grupo) para identificar possíveis diferenças entre proporções de complicação anestésica nos três grupos. Foram realizados os testes de Qui-quadrado e Exato de Fisher, bem como Análise de Variância. Os resultados foram avaliados sob um nível de significância de 5\% $(\alpha=0,05)$. O risco relativo (RR) foi calculado para os fatores de risco de interesse. Risco relativo é a incidência da complicação em um grupo dividido pela incidência no outro grupo, sendo uma medida usada para expressar a força da associação entre dois eventos, no caso, a variável versus a 
complicação. Ele indica quantas vezes o risco do evento é maior em um grupo, em relação ao outro. Essa correlação é maior quanto mais o valor do RR se afasta do valor 1 .

\section{RESULTADOS}

A amostra foi composta por 290 indivíduos de 1 a 17 anos de idade $(4,2 \pm 3,51)$, sendo 100 do grupo PCT, 79 do grupo PCO e 111 do grupo NPC. As variáveis demográficas foram comparáveis nos três grupos, exceto a média de idade, que foi maior no grupo PCT (Tabela I).

A ocorrência dos fatores de risco está apresentada na tabela II. Tabagismo dos pais, asma e convulsão foram os fatores de risco mais presentes na amostra.

Dezenove pacientes $(6,6 \%)$ tiveram pelo menos uma das seguintes complicações respiratórias: tosse, hipoxemia, laringoespasmo ou aspiração. Alguns pacientes tiveram mais de uma complicação. Nenhum paciente teve broncoespasmo. Tosse foi a complicação mais freqüente. A distribuição dessas complicações nos grupos pode ser vista na tabela III.

A maior parte das complicações ocorreu durante a indução ou despertar, como mostra a tabela IV. Alguns pacientes tiveram complicações em mais de um momento da anestesia. Não houve diferença estatística no risco de complicação respiratória entre pacientes portadores de PC e não-portadores $(p=0,912)$. A prevalência de complicação entre os três grupos foi de 4,0\% (PCT), 8,9\% (PCO) e 7,2\% (NPC). Não houve diferença no risco de complicações respiratórias entre os três grupos ( $p=0,401)$. Todas as complicações foram manuseadas adequadamente e evoluíram sem seqüelas. Apenas um paciente necessitou de intubação traqueal. Dos fatores de risco, apenas IVAS teve associação estatística com a ocorrência de complicação respiratória (Tabela V). A prevalência de IVAS entre os grupos foi de 7,0\% (PCT), $19,0 \%$ (PCO) e 16,2\% (NPC).

Dos 40 pacientes que apresentaram IVAS, 12 desenvolveram complicações respiratórias, ou seja, $30 \%$. O risco relativo de pacientes com IVAS, para desenvolver uma complicação, foi estimado em 10,71. Esse dado sugere uma forte correlação entre a presença de IVAS e a ocorrência de complicações respiratórias, e, para a amostra estudada, pacientes com infecções respiratórias apresentaram risco cerca de 10 vezes maior de desenvolver essas complicações em relação aos pacientes sem IVAS.

\section{DISCUSSÃO}

Apesar da incidência de PC se manter constante nos países desenvolvidos, a despeito dos avanços da medicina, não são muitos os estudos prospectivos envolvendo anestesia nesse grupo de pacientes. Essa escassez de publicações faz com que os livros que abordam o assunto o façam de forma sucinta, e muitas vezes com afirmações pouco documentadas ou com base em fracas evidências ${ }^{5-7}$.

Tabela II - Fatores de Risco, em Valores Absolutos e Relativos, Encontrados na Amostra Estudada

\begin{tabular}{lcc}
\hline Fatores de risco & No casos & Percentual \\
\hline Pais fumantes & 113 & $39 \%$ \\
Asma & 89 & $30,7 \%$ \\
Convulsão & 81 & $27,9 \%$ \\
Prematuridade & 74 & $25,5 \%$ \\
Incoordenação orofaríngea & 56 & $19,3 \%$ \\
IVAS & 40 & $13,8 \%$ \\
Alergia & 38 & $13,1 \%$ \\
Refluxo gastroesofágico & 36 & $12,4 \%$ \\
Pneumonia & 21 & $7,2 \%$ \\
Hidrocefalia & 15 & $5,2 \%$ \\
\hline
\end{tabular}

№ pacientes $=100 \%$.

IVAS - infecção de vias aéreas superiores.

Tabela I - Dados Demográficos dos Pacientes dos Diferentes Grupos que Compuseram a Amostra

\begin{tabular}{|c|c|c|c|c|}
\hline Variável & PCT & PCO & NPC & Total \\
\hline \multicolumn{5}{|l|}{ Sexo } \\
\hline Masculino & $48(48 \%)$ & $39(49,4 \%)$ & $61(55 \%)$ & 148 (51\%) \\
\hline Feminino & $52(52 \%)$ & $40(50,6 \%)$ & $50(45 \%)$ & 142 (49\%) \\
\hline 0 a 1 ano & 18 (18\%) & $14(17,7 \%)$ & $37(33,3 \%)$ & $69(23,8 \%)$ \\
\hline 2 a 5 anos & 44 (44\%) & $50(63,3 \%)$ & $57(51,4 \%)$ & $151(52,1 \%)$ \\
\hline Mais de 5 anos & 38 (38\%) & 15 (19\%) & $17(15,3 \%)$ & $70(24,1 \%)$ \\
\hline Média \pm DP & $5,9 \pm 4,58$ & $3,5 \pm 2,44$ & $3,2 \pm 2,27$ & $4,2 \pm 3,51$ \\
\hline
\end{tabular}


Tabela III - Complicações Respiratórias, em Números Relativos e Absoluto, Observadas nos Diferentes Grupos que Compuseram a Amostra

\begin{tabular}{lcccc}
\hline Complicação respiratória & PCT & PCO & NPC & Total \\
\hline Tosse & $3(3 \%)$ & $5(6,3 \%)$ & $6(5,4 \%)$ & $14(4,8 \%)$ \\
Hipoxemia & $0(0 \%)$ & $4(5,1 \%)$ & $3(2,7 \%)$ & $7(2,4 \%)$ \\
Laringoespasmo & $1(1 \%)$ & $2(2,5 \%)$ & $3(2,7 \%)$ & $6(2,1 \%)$ \\
Aspiração & $0(0 \%)$ & $1(1,3 \%)$ & $0(0 \%)$ & $1(0,3 \%)$ \\
Sem complicações & $96(96 \%)$ & $67(84,8 \%)$ & $99(89,2 \%)$ & $262(90,3 \%)$ \\
\hline
\end{tabular}

$\mathrm{N}^{\circ}$ pacientes por grupo $=100 \%$.

Tabela IV - Complicações Observadas nos Diferentes Momentos da Anestesia, em Números Relativos e Absolutos

\begin{tabular}{lcc}
\hline Momento da complicação anestésica & $\mathrm{N}^{\circ}$ casos & Percentual \\
\hline Indução & 8 & $2,8 \%$ \\
Manutenção & 1 & $0,3 \%$ \\
Despertar & 13 & $4,5 \%$ \\
Recuperação & 2 & $0,7 \%$ \\
\hline
\end{tabular}

$\mathrm{N}^{\circ}$ pacientes $=100 \%$.

Os efeitos de alguns fármacos usados em anestesia em pacientes com PC, dentre eles os bloqueadores neuromusculares ${ }^{8,9}$ e halogenados ${ }^{10-12}$, foram estudados previamente. Trabalhos relacionados com complicações de tipos específicos de procedimentos cirúrgicos nesses pacientes também já foram publicados ${ }^{13}$. Porém, não há estudos que visem a demonstrar os efeitos específicos da PC e doenças correlacionadas sobre a ocorrência de complicações anestésicas, sobretudo respiratórias.

A classificação do tipo de PC leva em consideração, sobretudo, a topografia, o acometimento motor e a gravidade das manifestações clínicas ${ }^{14}$. A tetraplegia espástica é a sua forma mais grave, e nela estão representados pacientes com seqüelas de lesão cerebral importante e com o maior número de doenças associadas.

Stasikelis e col. analisaram fatores relacionados com a ocorrência de complicações de curto prazo em pacientes com formas graves de PC submetidos a osteotomias. Foram analisadas apenas complicações relacionadas com o procedimento cirúrgico, como fraturas e úlceras de decúbito, além de morte. Das 79 crianças estudadas, três morreram de causas indefinidas após cinco meses e outras 17 tiveram alguma das ocorrências supracitadas (25\%). A média de idade das crianças que apresentaram alguma complicação foi de 105 meses. Os principais dados admitidos como fatores de risco encontrados foram a presença de gastrostomia e o uso de cadeira de rodas, o que sugere que se tratariam daqueles pacientes com acometimento neurológico
Tabela V - Probabilidades de Significância entre Fator de Risco e Ocorrência de Complicações Respiratórias

\begin{tabular}{lc}
\hline Fatores de risco & $p$ \\
\hline IVAS $^{*}$ & $<0,001^{(\mathrm{s})}$ \\
Prematuridade* $^{*}$ & 0,349 \\
Incoordenação orofaríngea* $^{*}$ & 0,546 \\
Pneumonia* $^{*}$ & 0,637 \\
Pais fumantes** $^{\star *}$ & 0,658 \\
Alergia* $^{*}$ & 0,724 \\
Asma* $^{* *}$ & 0,865 \\
Convulsão** $^{*}$ & 0,919 \\
Refluxo gastroesofágico* & $>0,999$ \\
\hline
\end{tabular}

IVAS - infecção de vias aéreas superiores.

* Exato de Fisher.

** Qui-quadrado de Yates.

(S) Significativo a 0,05 .

maior. Porém, este estudo se ateve às complicações ortopédicas, sem avaliar aquelas relacionadas com a anestesia, e seus resultados não podem ser extrapolados para o presente estudo.

No presente estudo, procuramos demonstrar se a PC, nas suas diversas formas, poderia ser considerada como fator de risco para o aparecimento de complicações respiratórias durante anestesia geral, não só pela lesão neurológica em si, mas também em virtude dos problemas associados ao quadro. Apesar da recorrente preocupação nos artigos de revisão sobre a participação desses problemas no possível aumento na ocorrência de complicações ${ }^{15}$, os resultados do presente estudo não confirmaram tal suspeita.

Com o objetivo de melhor avaliar esses efeitos, indivíduos com tetraplegia espástica compuseram um grupo distinto daqueles com formas menos graves de PC, bem como dos pacientes sem PC. A análise dos resultados não demonstrou qualquer diferença na ocorrência de complicações entre os grupos estudados. Os resultados sugerem que a PC, 
independentemente do tipo clínico, não é um fator de risco para o aumento de complicações respiratórias durante anestesia geral. Pacientes com a forma de PC que cursa com acometimento sistêmico mais grave (tetraplegia espástica) tiveram prevalência de complicações semelhantes àqueles com formas mais brandas de $\mathrm{PC}$ ou sem diagnóstico de PC. Todos os grupos estudados apresentaram percentual de complicações semelhantes aos encontrados na literatura ${ }^{16}$.

Alguns fatores podem ter contribuído para esses resultados. Todos os pacientes foram anestesiados com sevoflurano e máscara laríngea. O sevoflurano é um anestésico pouco irritante para as vias aéreas, com boa margem de segurança e que permite indução inalatória suave e despertar rápido 17. Tait e col. demonstraram que o manuseio das vias aéreas com máscara laríngea também parece diminuir a incidência de eventos respiratórios durante anestesia geral quando comparada com a intubação traqueal, sobretudo nos pacientes com IVAS ${ }^{18}$.

Além disso, todos os pacientes foram submetidos à tomografia computadorizada, um procedimento de curta duração e sem estímulos dolorosos. Essa uniformidade relacionada com o procedimento e com a anestesia permitiu melhor avaliação das variáveis estudadas, com uma diminuição dos fatores que poderiam acarretar algum viés proveniente do método aplicado.

Outras variáveis associadas aos componentes da amostra e à $P C$ que poderiam contribuir para o aumento no número de complicações também foram investigadas. A presença de incoordenação orofaríngea e de refluxo gastroesofágico, considerados como prováveis fatores de risco para surgimento de complicações nesses pacientes ${ }^{3}$, não foi responsável por aumento de suas ocorrências.

Da mesma forma, prematuridade, tabagismo dos pais e asma não concorreram para o aumento dessas complicações. Apesar de história de prematuridade ter sido identificada em estudos anteriores como fator de risco isolado em pacientes com IVAS, não ficaram claros os reais motivos desse resultado ${ }^{16}$. Skolnick e col. encontraram aumento na prevalência de eventos respiratórios durante anestesia geral em crianças expostas passivamente a fumaça oriunda do cigarro de pais tabagistas ${ }^{19}$. Nos pacientes observados no atual estudo a presença dessa variável não se constituiu em risco adicional de complicações respiratórias. Porém, deve-se levar em conta o risco de omissão no relato de alguns pais, receosos dos efeitos negativos do seu hábito sobre a saúde dos filhos ${ }^{16}$.

O único fator de risco associado a aumento da prevalência de complicações respiratórias neste estudo foi a presença de infecção das vias aéreas. Pacientes que apre- sentavam sintomas de IVAS tiveram prevalência maior de complicações respiratórias, corroborando estudos anteriores ${ }^{16,20,21}$. A maior parte ocorreu na indução ou no despertar e, em concordância com esses estudos, não houve complicações graves, e todas foram devidamente manuseadas e evoluíram para resolução sem seqüelas. $O$ fato de ter-se encontrado prevalência maior de complicações respiratórias nos grupos em que a IVAS foi mais freqüente, (pacientes sem PC ou com outras formas de PC) contribui para reforçar a possível relação de causa/efeito entre esses dois fatores.

Há algumas limitações no presente estudo. Não houve distribuição aleatória da amostra ou método duplamente encoberto na avaliação, o que pode ter acrescido algum grau de viés de seleção ou do observador. Porém, a ordem de entrada dos pacientes no estudo foi independente da vontade dos autores, sendo os exames realizados de forma consecutiva pelo período de um ano. Além disso, o número expressivo de pacientes tetraplégicos que compuseram a amostra, não encontrado em nenhum outro estudo prospectivo sobre anestesia em PC, sugere que caso houvesse diferença clinicamente importante entre os grupos na ocorrência de complicações esta seria apontada nos resultados.

Também o diagnóstico de PC pode suscitar alguma dúvida quanto a sua classificação, sobretudo nos casos menos graves. Contudo, procurou-se utilizar definições clínicas padronizadas ${ }^{1}$, além da confirmação do diagnóstico junto aos profissionais médicos responsáveis pelas crianças. Todas as informações do prontuário, incluindo métodos de imagem, foram utilizadas para confirmação do quadro clínico. Além disso, pacientes com tetraplegia espástica dificilmente apresentam dificuldades na sua caracterização, em virtude da gravidade do acometimento motor e neurológico que apresentam.

Os resultados desse estudo sugerem que a PC, mesmo nas suas formas mais graves de acometimento sistêmico, não constitui fator de risco determinante para ocorrência de complicações respiratórias durante anestesia geral, sobretudo em procedimentos de curta duração como a realização do exame de tomografia computadorizada. A presença de IVAS foi confirmada como importante fator de risco no aparecimento de complicações respiratórias durante anestesia geral. Estudos futuros poderão demonstrar se esses resultados são aplicáveis a outros procedimentos anestésicocirúrgicos em indivíduos com PC.

\section{AGRADECIMENTO}

Agradecemos ao estatístico Luiz Sérgio Vaz, pelo auxílio na interpretação dos dados. 


\section{Respiratory Complications in Patients with Cerebral Palsy Undergoing General Anesthesia}

Sérgio Silva de Mello, TSA, M.D.; Ronaldo Soares Marques, TSA, M.D.; Renato Ângelo Saraiva, TSA, M.D.

\section{INTRODUCTION}

Cerebral palsy (CP) represents a group of disorders in the development of movements and posture, secondary to nonprogressive changes in the developing brain of fetuses and children, which limits activities. This motor disorder is frequently accompanied by changes in sensation, cognition, communication, perception, behavior, and seizures ${ }^{1}$. The incidence of children who survive organic aggressions endured in the pre-, peri-, or post-natal period has not changed in the last decades in developed countries ${ }^{2}$. During the course of their lives, a significant number of those patients undergoes anesthesia for propaedeutical or therapeutic purposes. The presence of diseases associated with the cerebral lesion, such as gastroesophageal reflux (GERD), oropharyngeal dysfunction, and accumulation of secretion, besides seizures and motor incoordination, can contribute to the increase in the incidence of respiratory complications during general anesthesia in those patients ${ }^{3,4}$.

The goal of this study was to determine the prevalence of respiratory complications in children with $\mathrm{CP}$ undergoing general inhalational anesthesia (GIA) for CT scan compared to healthy children. Besides that, other risk factors related with the development of those complications were also evaluated.

\section{METHODS}

This study was approved by the Ethics Committee of the Institution, and parents or legal guardians signed the informed consent. The study population was composed of 290 patients, with ages ranging from 1 to 17 years, scheduled for a CT scan of the brain under general anesthesia, from June $1^{\text {st }}, 2001$ to June $1^{\text {st }}, 2002$; patients were divided in 3 groups: patients with cerebral palsy with spastic quadriplegia (CPQ); patients with other forms of $C P$, i.e., spastic diplegia, spastic hemiplegia, and choreoathetosis (CPO); and children without CP (NCP). Patients with genetic syndromes, other diseases affecting the central nervous system (CNS), signs of upper respiratory infection (URI) with systemic repercussions, or bacterial infection of the lower airways, were excluded from the study.

Before the procedure, the legal guardians of the patients were asked to fill out a study form containing demographic information about the family, history of current or recent URI ( $<3$ weeks), asthma, prematurity ( $<37$ weeks), and smoking history of the parents. The presence of asthma, oropharyngeal dysfunction diagnosed by videofluoroscopy, severe GERD diagnosed by endoscopy, use of anti-reflux medication, seizures and the use of anti-seizure medications, and history of recurring pneumonia and allergies were also evaluated. The type of CP was classified based on the data in the charts of the patients and confirmed with the patient's attending.

Anesthesia - Every patient underwent general inhalational anesthesia with sevoflurane associated with $\mathrm{N}_{2} \mathrm{O}$, in a circuit without valves and without $\mathrm{CO}_{2}$ absorber, monitoring of cardiovascular and respiratory parameters, and the final expired concentration (alveolar) of the anesthetic was maintained at $0.5 \mathrm{CAM}$ for the duration of the procedure. Maintenance of the airways was accomplished with a laryngeal mask, allowing spontaneous ventilation during the exam, with $\mathrm{P}_{\mathrm{ET}} \mathrm{CO}_{2}$ and $\mathrm{SpO}_{2}$ levels within normal limits. Eventual difficulties during insertion and adaptation of the laryngeal mask were recorded, as well as the duration of the anesthesia.

Characterization of respiratory events - The following signs and symptoms were considered ventilatory problems and recorded as such in the anesthesia and other appropriate forms: hypoxemia, defined as $\mathrm{SpO}_{2}<90 \%$ for more than 20 seconds, laryngeal spasm, bronchospasm, severe coughing for more than 15 seconds, and clinical evidence of pulmonary aspiration of gastric contents. The time and severity of the intercurrence were also recorded: induction, maintenance, awakening, and post-anesthetic (1-4); without intercurrence, mild, moderate or severe (1-4).

The degree of the intervention was also recorded: 1 . Simple: oxygen $\left(\mathrm{O}_{2}\right)$ by mask; 2 . Moderate: $\mathrm{O}_{2}$ by mask + succinylcholine or atropine; 3 . Complex: $\mathrm{O}_{2}+$ drugs + tracheal intubation; 4. Cardiopulmonary resuscitation (CPR).

The success of the measures was evaluated throughout the evolution period: 1. Favorable; 2. Unfavorable - sequela or death. The following parameters were compared: frequency of complications, time of onset, type of intervention needed, and evolution.

The software SPSS ${ }^{\circledR}$, version 10.0.1, was used for the statistical analysis. Assuming that the risk of respiratory complications in children with CP would be approximately $5 \%$, and that the prevalence in children with milder forms of CP would be similar, we expected the empirical prevalence to be at least four times greater in children with the most severe form of CP (spastic quadriplegia). Considering a power of 0.8 (1- $\beta)$ and $\alpha=0.05$, the suggested study population would be composed by 227 children (76 per group) to identify possible differences in the rates of anesthetic complications among the three groups. The Chi-square test, Fisher exact test, and ANOVA were used. Results were evaluated considering significant a level of $5 \%(\alpha=0.05)$. The 
relative risk $(\mathrm{RR})$ for the risk factors of interest was determined. Relative risk is the incidence of complication in a group of individuals divided by the incidence in the other group, and it is used to express the power of the association between two events, in this case the parameter versus the complication. It indicates how many times greater is the risk of an event in a group compared with another group. The farther this value is from one, the higher the correlation.

\section{RESULTS}

The study population was composed of 290 patients, with ages ranging from 1 to 17 years $(4.2 \pm 3.51), 100$ in the $\mathrm{CPQ}$ group, 79 in the CPO, and 111 in the NCP. Demographic parameters in all three groups were similar, except age, which was greater in the CPQ group (Table I).

Table II shows the incidence of risk factors. Parents who smoked, asthma, and seizures were the most prevalent risk factors in this population.

Nineteen patients $(6.6 \%)$ presented at least one of the following respiratory complications: cough, hypoxemia, laryngeal spasm, or aspiration. Some patients developed more than one complication. Patients did not develop bronchospasm. Cough was the most frequent complication. Table III shows the distribution of those complications among the three groups.

The majority of complications developed during the induction or awakening, as is demonstrated in Table IV. Some patients developed complications in more than one moment of the procedure.

There were no statistically significant differences in the risk of respiratory complications among patients with $\mathrm{CP}$ and those without CP ( $p=0.912)$. The prevalence of complications among the groups was $4.0 \%$ (CPQ), $8.9 \%$ (CPO), and $7.2 \%$ (NCP). There were no differences in the risk of respiratory complications among the three groups $(p=0.401)$.
All complications were handled properly and evolved without sequelae. Only one patient required tracheal intubation.

Among the risk factors, only URI demonstrated a statistical association with the development of respiratory complications (Table V). The prevalence of URI among the groups was $7 \%$ (CPQ), $19.0 \%$ (CPO), and $16.2 \%$ (NCP).

Only twelve of the 40 patients, i.e. $30 \%$, who presented URI developed respiratory complications. The relative risk of patients with URI of developing a complication was estimated as 10.71. This datum suggests a strong correlation between the presence of URI and the development of respiratory complications; in this study population, patients with respiratory infection presented a risk 10 times greater of developing respiratory complications, when compared with patients without URI.

Table II - Absolute and Relative Numbers of Risk Factors in the Study Population

\begin{tabular}{lcc}
\hline Risk factors & $N^{\circ}$ of cases & Percentage \\
\hline Smoking - parents & 113 & $39 \%$ \\
Asthma & 89 & $30.7 \%$ \\
Seizures & 81 & $27.9 \%$ \\
Prematurity & 74 & $25.5 \%$ \\
Oropharyngeal dysfunction & 56 & $19.3 \%$ \\
URl & 40 & $13.8 \%$ \\
Allergy & 38 & $13.1 \%$ \\
Gastroesophageal reflux & 36 & $12.4 \%$ \\
Pneumonia & 21 & $7.2 \%$ \\
Hydrocephalus & 15 & $5.2 \%$ \\
\hline
\end{tabular}

$\mathrm{N}^{\circ}$ of patients $=100 \%$.

URI - upper respiratory infection.

Table I - Demographic Data of Patients in the Different Groups

\begin{tabular}{lcccc}
\hline Parameter & CPQ & CPO & NCP & Total \\
\hline $\begin{array}{l}\text { No of patients } \\
\text { Gender }\end{array}$ & $100(34.5 \%)$ & $79(27.2 \%)$ & $111(38.3 \%)$ & 290 \\
$\quad$ Male & $48(48 \%)$ & $39(49.4 \%)$ & $61(55 \%)$ & $148(51 \%)$ \\
Female & $52(52 \%)$ & $40(50.6 \%)$ & $50(45 \%)$ & $142(49 \%)$ \\
Age & & & $37(33.3 \%)$ & $69(23,8 \%)$ \\
0 to 1 year & $18(18 \%)$ & $14(17.7 \%)$ & $57(51.4 \%)$ & $151(52.1 \%)$ \\
2 to 5 years & $44(44 \%)$ & $50(63.3 \%)$ & $17(15.3 \%)$ & $70(24.1 \%)$ \\
$>5$ years & $38(38 \%)$ & $15(19 \%)$ & $3.2 \pm 2.27$ & $4.2 \pm 3.51$ \\
Mean \pm SD & $5.9 \pm 4.58$ & $3.5 \pm 2.44$ & & \\
\hline
\end{tabular}


Table III - Relative and Absolute Numbers of Respiratory Complications Observed in the Study Groups

\begin{tabular}{lcccc}
\hline Respiratory complications & CPQ & CPO & NCP & Total \\
\hline Cough & $3(3 \%)$ & $5(6.3 \%)$ & $6(5.4 \%)$ & $14(4.8 \%)$ \\
Hypoxemia & $0(0 \%)$ & $4(5.1 \%)$ & $3(2.7 \%)$ & $7(2.4 \%)$ \\
Laryngeal spasm & $1(1 \%)$ & $2(2.5 \%)$ & $3(2.7 \%)$ & $6(2.1 \%)$ \\
Aspiration & $0(0 \%)$ & $1(1.3 \%)$ & $0(0 \%)$ & $1(0.3 \%)$ \\
Without complications & $96(96 \%)$ & $67(84.8 \%)$ & $99(89.2 \%)$ & $262(90.3 \%)$ \\
\hline
\end{tabular}

$\mathrm{N}^{\circ}$ of patients per group $=100 \%$.

Table IV - Relative and Absolute Numbers of Complications Observed in Different Moments of the Anesthesia

\begin{tabular}{lcc}
\hline Moment of the anesthetic complication & $\mathrm{N}^{\circ}$ of cases & Percentage \\
\hline Induction & 8 & $2.8 \%$ \\
Maintenance & 1 & $0.3 \%$ \\
Awakening & 13 & $4.5 \%$ \\
Recovery & 2 & $0.7 \%$ \\
\hline
\end{tabular}

$\mathrm{N}^{\circ}$ of patients $=100 \%$.

\section{DISCUSSION}

Although the incidence of CP has remained constant in developed countries, despite the advances in medicine, there are few prospective studies in the literature regarding anesthesia in those patients. Therefore, textbooks on the subject present a brief discussion, and very often present statements that have not been widely documented or that are based on weak evidence ${ }^{5-7}$.

The effects of some of the drugs used in anesthesia in patients with CP, such as neuromuscular blockers ${ }^{8,9}$ and halogenated compounds ${ }^{10-12}$, have already been studied. There are also, in the medical literature, studies on the complications of specific surgical procedures in those patients ${ }^{13}$. However, there are no studies demonstrating specific effects of CP and related disorders on the development of anesthetic complications, especially respiratory complications.

The classification of CP considers, mainly, the topography, motor deficit, and severity of clinical manifestations ${ }^{14}$. Spastic quadriplegia is the most severe form of $\mathrm{CP}$, and patients with this form of the disease have important cerebral lesions and more associated disorders.

Stasikelis et al. analyzed the factors related with the development of short term complications in patients with severe forms of CP undergoing osteotomies. Only complications related to the surgical procedure, such as fractures and decubitus ulcers, besides death, were analyzed. Of the 79 patients in the study, three died 5 months later of unknown causes and 17 (25\%) developed some of the com-
Table V - Probability of Significance Between Risk Factor and the Development of Respiratory Complications

\begin{tabular}{lc}
\hline Risk factors & $p$ \\
\hline $\mathrm{URI}^{*}$ & $<0.001^{(\mathrm{s})}$ \\
Prematurity * $^{*}$ & 0.349 \\
Oropharyngeal dysfunction * & 0.546 \\
Pneumonia * & 0.637 \\
Smoking (parents) ** & 0.658 \\
Allergy * & 0.724 \\
Asthma ** & 0.865 \\
Seizures ** & 0.919 \\
Gastroesophageal reflux * & $>0.999$ \\
\hline
\end{tabular}

URI - upper respiratory infection.

* Fisher Exact.

** Yates' Chi-square test.

(S) Significant at 0.05 .

plications mentioned before. The mean age of the children who developed any complication was 105 months. The main factors considered risk factors were the presence of gastrostomy and being on a wheel chair, indicating patients with more severe neurologic damage. However, this study focused on orthopedic complications, and did not evaluate complications related with the anesthesia; therefore, their results cannot be extrapolated to the present study.

In our study, we tried to demonstrate whether the different types of CP could be considered risk factors for the development of respiratory complications during general anesthesia, not only due to the neurological damage, but also secondary to the problems associated with their baseline condition. Despite the recurring concern of revision papers regarding the influence of those problems in the possible increased rate of complications ${ }^{15}$, the results of the present study did not confirm this suspicion.

In order to better evaluate those effects, children with spastic quadriplegia were in a group of their own, separated from patients with milder forms of CP and from children without 
CP. Analysis of the results did not demonstrate any differences in the rate of complications among the study groups. The results suggest that $\mathrm{CP}$, regardless of the clinical type, is not a risk factor for the increased rate of respiratory complications during general anesthesia. The rate of complications in patients with the type of $\mathrm{CP}$ that presents more severe systemic involvement (spastic quadriplegia) was similar to those patients with milder types of CP or without CP. All three groups presented a rate of complication similar to that reported in the literature ${ }^{16}$.

Some factors might have contributed to the results of this study. Patients were anesthetized with sevoflurane and laryngeal mask. Sevoflurane causes little irritation of the airways, and has a wide safety margin, allowing a trouble free induction and fast arousal ${ }^{17}$. Tait et al. demonstrated that handling of the airways with the laryngeal mask also seems to reduce respiratory complications during general anesthesia when compared with tracheal intubation, especially in patients with URI ${ }^{18}$.

Besides, all patients had a CT scan done, a short lasting procedure that has no painful stimuli. This uniformity related with the procedure and anesthesia allowed for better evaluation of the parameters studied, such as reduction of the factors that could cause any problems caused by the method used.

Other factors regarding the components of the cohort and $\mathrm{CP}$ that could have contributed to an increase in the number of complications were also evaluated. The presence of oropharyngeal dysfunction and gastroesophageal reflux, considered probable risk factors for the development of complications ${ }^{3}$, were not responsible for an increase in the rate of complications.

Likewise, prematurity, parents who smoke, and asthma did not cause an increase in the rate of those complications. Although prior studies have identified prematurity as an isolated risk factor in patients with URI for an increase in complications, the true reasons of this result were not clear ${ }^{16}$. Skolnick et al. reported an increase in the prevalence of respiratory complications during general anesthesia in children with passive exposure to cigarette smoke ${ }^{19}$. In our study, passive exposure was not an additional risk factor for respiratory complications. However, one should take into account the lack of report of this variable by parents or legal guardians, who would be concerned about the negative impact of their smoking habit in the health of their children ${ }^{16}$. The only risk factor associated with an increase in the prevalence of respiratory complications in the present study was the presence of infection of the airways. The prevalence of respiratory complications was higher in patients with symptoms of URI, which corroborates the results of prior studies ${ }^{16,20,21}$. The majority of complications occurred during induction or awakening but, similar to other studies, there were no severe complications, and all of them were properly managed, with a good evolution, and resolved without sequelae. The increased prevalence, in this study, of res- piratory complications in patients with URI (patients without $\mathrm{CP}$ and with other forms of $\mathrm{CP}$ ) strengthens the possible cause/effect relationship between those factors.

The present study has some limitations. Patients were not distributed at random and the evaluation was not double blind, what might have influenced the selection of the observer. However, the order of patient entry in the study was not dependent on the will of the observer, and the exams were consecutively performed during one year. Besides, the expressive number of quadriplegic CP patients, which is not found in any other prospective study on anesthesia in CP, suggests that, if there were a clinically significant difference among the groups regarding the rate of complications, this would be evident in the present study.

The diagnosis of $\mathrm{CP}$ can also raise some doubts regarding their classification, especially in less severe cases. However, we tried to use standard clinical definitions ${ }^{1}$, and confirmed the diagnosis with the attending physicians. The information in the charts of the patients, including diagnostic imaging, was used to confirm the clinical picture. Besides, patients with spastic quadriplegia were not difficult to diagnose, due to the severity of the motor and neurologic deficit.

The results of this study suggest that, even in the most severe types, CP does not represent a risk factor for the development of respiratory complications during general anesthesia, especially in procedures of short duration, such as a CT scan. It confirmed that URI is an important risk factor for the development of those complications during general anesthesia. Future studies might demonstrate whether those results are valid for other anesthetic-surgical procedures in patients with $\mathrm{CP}$.

\section{ACKNOWLEDGEMENTS}

We would like to acknowledge the help of the statistician Luiz Sérgio Vaz on the interpretation of the results.

\section{REFERÊNCIAS - REFERENCES}

01. Bax M, Goldestein M, Rosenbaum P et al. - Proposed definition and classification of cerebral palsy. Dev Med Child Neurol 2005; 47:571-576.

02. Aicardi J, Bax M - Cerebral Palsy, em: Aicardi J - Diseases of the Nervous System in Childhood, $2^{\text {nd }}$ Ed, London, Mac Keith, 1999;210-240.

03. Wongprasartsuk $P$, Rosenbaum $P$ - Cerebral palsy and anaesthesia. Paediatr Anaesth 2002;12:296-303.

04. Maranhão MVM - Anestesia e paralisia cerebral. Rev Bras Anestesiol, 2005;55:680-702.

05. Salem MR, Klowden AJ - Anesthesia for Orthopedic Surgery, em: Gregory GA - Pediatric Anesthesia, $4^{\text {th }}$ Ed, Philadelphia, Churchill Livingstone, 2002;617-662.

06. Zuckerberg AL, Yaster M - Anesthesia for Orthopedic Surgery, em: Motoyama EK, Davis PJ — Smith's Anesthesia for Infants and Children, $6^{\text {th }}$ Ed, St Louis, Mosby, 1996;605-632. 
07. McLeod ME, Creighton RE - Central Nervous System Diseases, em: Katz J, Steward DJ - Anesthesia and Uncommon Pediatric Disease, $2^{\text {nd }} E d$, Philadelphia, WB Saunders, 1993;74-99.

08. Hepaguslar H, Ozzeybek D, Elar Z - The effect of cerebral palsy on the action of vecuronium with or without anticonvulsants. Anaesthesia, 1999;54:593-596.

09. Theroux MC, Brandon BW, Zagnoev M - Dose response of succinylcholine at the adductor pollicis of children with cerebral palsy during propofol and nitrous oxide anesthesia. Anesth Analg, 1994;79:761-765.

10. Frei FJ, Haemmerle MH, Brunner R et al. - Minimum alveolar concentration for halothane in children with cerebral palsy and severe mental retardation. Anaesthesia, 1997;52:1056-1060.

11. Choudhry DK, Brenn BR - Bispectral index monitoring: a comparison between normal children and children with quadriplegic cerebral palsy. Anesth Analg, 2002;95:1582-1585.

12. Mello SM, Saraiva RA - Alterações eletroneurofisiológicas em anestesia com sevoflurano: estudo comparativo entre pacientes saudáveis e pacientes com paralisia cerebral. Rev Bras Anestesiol, 2003;53:150-159.

13. Stasikelis PJ, Lee DD, Sullivan CM - Complications of osteotomies in severe cerebral palsy. J Pediatr Orthop 1999; 19:207-210.

14. Campos da Paz Jr A, Burnett SM, Nomura AM - Neuromuscular Affections in Children, em: Duthie RB, Bentley G - Mercer's Orthopaedic Surgery, $9^{\text {th }}$ Ed, New York, Oxford University, 1996; 444-473.

15. Theroux MC, Akins RE - Surgery and anesthesia for children who have cerebral palsy. Anesthesiol Clin North Am, 2005;23:733743.

16. Tait AR, Shobha M, Voepel-lewis T et al. - Risk factors for perioperative adverse respiratory events in children with upper respiratory tract infections. Anesthesiology 2001;95:299-306.

17. Eger II El - The pharmacology of inhaled anesthetics. Semin Anesth Perioper Med Pain, 2005;24:89-100.

18. Tait AR, Pandit UA, Voepel-lewis T et al. - Use of the laryngeal mask airway in children with upper respiratory tract infections: a comparison with endotracheal intubation. Anesth Analg, 1998;86:706-711.

19. Skolnick ET, Vomvolakis MA, Buck KA - Exposure to environmental tobacco smoke and the risk of adverse respiratory events in children receiving general anesthesia. Anesthesiology, 1998;88:1144-1153.

20. Parnis SJ, Barker DS, Van der Walt JH - Clinical predictors of anaesthetic complications in children with respiratory tract infections. Paediatr Anaesth, 2001;11:29-40.

21. Tait AR, Malviya $S$ - Anesthesia for the child with an upper respiratory tract infection: still a dilemma? Anesth Analg, 2005; 100:59-65.

\section{RESUMEN}

Mello SS, Marques RS, Saraiva RA - Complicaciones Respiratorias en Pacientes con Parálisis Cerebral Sometidos a la Anestesia General.

JUSTIFICATIVA Y OBJETIVOS: La anestesia en pacientes con parálisis cerebral (PC) puede representar un desafío para el anestesiólogo. Este estudio prospectivo tuvo como objetivo determinar la prevalencia y el riesgo de complicaciones respiratorias en niños con PC sometidos a anestesia general inhalatoria para tomografía computadorizada.

MÉTODO: Participaron del estudio pacientes con edades entre 1 y 17 años, estado físico ASA I a III, sometidos a AGI con sevoflurano y máscara laríngea para TC en el período de junio/2002 a junio/ 2003, divididos en 3 grupos: PC tetraplégicos (PCT), Otros tipos de PC (PCO), y paciente sin PC (NPC). Los padres o responsables respondieron a un cuestionario con preguntas sobre el historial médico de los pacientes, infección de vías aéreas superiores (IVAS), asma, convulsión, no coordinación oro faríngea, reflujo gastroesofágico, etc. Datos sobre la incidencia y la gravedad de las complicaciones respiratorias fueron recolectados proscpectivamente (tos, bronco espasmo, laringo espasmo, hipoxemia, aspiración). La muestra fue calculada para una incidencia esperada de $5 \%$ en el grupo NPC, con una diferencia de $15 \%$ entre los grupos $(\alpha=0,05$ y $\beta=0,1)$, utilizando los tests del Chi-cuadrado, exacto de Fisher $y$ t de Student.

RESULTADOS: Conformaron la muestra 290 pacientes divididos en los grupos de la siguiente forma: PCT - 100, PCO - 79 y NPC - 111. No hubo diferencia en la prevalencia de complicaciones respiratorias entre los grupos PCT (4\%), PCO (8,9\%) y NPC (7,3\%). Hubo una asociación entre la presencia de IVAS y la incidencia de complicaciones (riesgo relativo 10,71 ).

CONCLUSIONES: Niños con parálisis cerebral tipo tetraplegia espástica no parecen correr riesgo aumentado de complicaciones respiratorias durante la anestesia general inhalatoria con sevoflurano y máscara laríngea. El estudio confirma IVAS como factor de riesgo para la incidencia de esas complicaciones. 